Boston University School of Law

Scholarly Commons at Boston University School of Law

Faculty Scholarship

2001

Testing Poor Pregnant Women for Cocaine: Physicians as Police Investigators

George J. Annas

Follow this and additional works at: https://scholarship.law.bu.edu/faculty_scholarship

Part of the Health Law and Policy Commons 
Legal Issues in Medicine

\section{Testing Poor Pregnant Women For Cocaine - Physicians as Police Investigators}

\author{
George J. AnnAS, J.D., M.P.H.
}

$\mathrm{I}$ N 1989, Supreme Court Justice Thurgood Marshall surmised that "declaring a war on illegal drugs is good public policy ... . [but] the first, and worst, casualty of war will be the precious liberties of our citizens." The same year, in the midst of President George Bush's "war on drugs," the Medical University of South Carolina initiated a program to screen selected pregnant patients for cocaine and to provide positive test results to the police. ${ }^{2}$ At a time of high public concern about "cocaine babies," this program seemed reasonable to the university and local public officials. Drug-screening programs in other groups of people had been found constitutional by the Supreme Court, ${ }^{1,3}$ and it was beginning to appear that the war on drugs would claim the Fourth Amendment, which prohibits unreasonable searches, as one of its first casualties. ${ }^{4}$

In this context, it seemed as if the university's policy might survive a constitutional challenge - and it did in the Fourth Circuit Court of Appeals, which in 1999 rejected a challenge to the policy. ${ }^{5}$ In March 2001, however, the Supreme Court found that the policy was constitutionally deficient. ${ }^{6}$

THE POLICY OF THE MEDICAL UNIVERSITY OF SOUTH CAROLINA

The university policy, developed with the local police department, ultimately provided that a pregnant woman who tested positive for cocaine would be given a letter from the prosecutor saying that if she successfully completed a drug-treatment program she would not be prosecuted. If she did not complete the program, however, the police would be notified and she would be arrested and charged with drug distribution and child neglect. If she tested positive at the time of delivery, she would be arrested immediately and charged with child neglect. ${ }^{2}$ Pregnant women were to be tested for cocaine if they met any of nine criteria: the receipt of no prenatal care, of late prenatal care after 24 weeks' gestation, or of incomplete prenatal care; abruptio placentae; intrauterine fetal death; preterm labor "of no obvious cause"; intrauterine growth retardation "of no obvious cause"; previously known drug or alcohol abuse; and unex-

From the Health Law Department, Boston University School of Public Health, Boston. plained congenital anomalies. ${ }^{6}$ The hospital's general counsel was not entirely supportive of the program and wrote to the state's attorney general that he would "prefer to have the mothers sign an informed consent to the drug screen [and that] the DSS [Department of Social Services] be notified rather than law enforcement. . . . The other weakness in this program is that the main prosecutions have been against black indigent mothers."

Under the policy, which was in effect until 1994, 253 women tested positive for cocaine. Thirty of them were arrested, and two were sentenced to prison. Ten of the women who were arrested sued for violation of their constitutional rights. They were represented by the American Civil Liberties Union. Nine of the 10 were black. All were poor. Six had been arrested at the hospital, shortly after giving birth. Three had been arrested when they failed to complete a drugtreatment program. The only white woman of the 10 was told at a prenatal visit that she must either voluntarily admit herself to a psychiatric unit or be arrested. She spent 30 days in the unit before giving birth. The lawsuit was filed in 1993.

The university discontinued its policy in September 1994 in a settlement agreement with the Civil Rights Division of the Department of Health and Human Services, which was investigating whether the policy violated the Civil Rights Act. In that same month, the Office for Protection from Research Risks of the National Institutes of Health, after investigating a complaint, notified the university that its cocaine-testing policy constituted a research project that had not been reviewed by the institutional review board, a violation of federal regulations.

\section{THE FOURTH AMENDMENT}

Because the 10 women were suing for monetary damages, and because the university would not agree to discontinue using noncriminal coercive measures, including civil commitment, their lawsuit against the university, the city, and the police continued even though the arrest policy had been abandoned. The Fourth Amendment provides that "the right of the people to be secure in their persons, houses, papers, and effects, against unreasonable search and seizures, shall not be violated, and no Warrants shall issue, but upon probable cause, supported by Oath or affirmation, and particularly describing the place to be searched, and the person or things to be seized." The amendment prohibits unreasonable searches by the police or those working for the police without a warrant or the consent of the person searched, unless there is some "special non-law-enforcement need" for the search that makes it reasonable. At the trial, the defendants offered two defenses for testing the urine of the pregnant women for cocaine: first, the women had in fact consented to the searches, so no warrant was necessary; and second, even without con- 
sent, the searches were justified by a "special nonlaw-enforcement need." The trial court rejected the second defense but put the first one to the jury, instructing the jury that it had to find in favor of the women unless it found they had consented to the search. The jury found in favor of the defendants. The women appealed.

The Fourth Circuit Court of Appeals affirmed the finding in a two-to-one opinion, but for a different reason. ${ }^{5}$ The circuit court held that the searches were reasonable under the Fourth Amendment as a matter of law because of the "special need" to protect women and children from the complications of the maternal use of cocaine. ${ }^{5}$ The dissenting judge disagreed and also concluded that the evidence of consent was insufficient to sustain the jury's verdict. ${ }^{5}$ The women appealed again.

\section{THE MAJORITY DECISION OF THE SUPREME COURT}

In a six-to-three opinion, the Supreme Court reversed the decision of the circuit court regarding the special-needs exception and sent the case back to the circuit court for a factual determination of whether the women had actually consented to the search. Justice John Paul Stevens wrote the opinion of the Court, focusing on the special-needs exception. That exception had been adopted in 1989 by the Supreme Court in two cases. One involved testing railway workers for drugs and alcohol after major train accidents. The other involved testing U.S. Customs employees for drug use when they were seeking sensitive jobs or promotions. ${ }^{1,3}$ The special-needs exception had also been used to justify the drug testing of high-school students participating in interscholastic sports. ${ }^{7}$ It had, however, been found insufficient to make drug testing a condition for filing candidate papers for certain state offices. $^{8}$

Justice Stevens concluded that in each of these cases the Court had used a "balancing test that weighed the intrusion on the individual's interest in privacy against the 'special needs' that supported the program." The purpose of testing railway workers, for example, was to try to learn the cause of accidents so as to prevent them; the Customs employees were tested to make sure they could not easily be compromised by drug smugglers; high-school athletes were tested to see whether they were eligible for an extracurricular activity. Stevens observed that the non-law-enforcement purpose of the drug tests in all these special-needs cases was clear and that precautions were taken to ensure that the police did not obtain the results.

Justice Stevens found that the "critical difference" between the previous special-needs cases and this one was the "nature of the 'special need' asserted for the warrantless search." Specifically, Stevens concluded that whereas the special need in each of the previous cases was "divorced from the State's general interest in law enforcement," in South Carolina "the central and indispensable feature of the [drug-testing] policy from its inception was the use of law enforcement to coerce the patients into substance abuse treatment."

The drug-testing policy of the Medical University of South Carolina, Stevens concluded, was "ultimately indistinguishable from the [state's] general interest in crime control." This conclusion followed from the fact that the police helped to develop the program, were involved in its day-to-day administration, determined the procedures to be followed, and coordinated the "timing and circumstances of the arrests with [university] staff," and that women were jailed. In Justice Stevens's words, "The threat of law enforcement may ultimately have been intended as the means to an end, but the direct and primary purpose of [the university's] policy was to ensure the use of those means. In our opinion, this distinction is critical."

The Court sent the question of whether the women had consented back to the circuit court for further consideration. According to the original instructions to the jury, in order to find that the women had provided informed consent, the jury had to conclude not only that the women consented to have a urine sample taken for medical testing but also that they consented to have their urine tested for cocaine knowing that the results of the testing would be turned over to the police. Even though the jury did find that consent had been provided, the dissenting judge in the Fourth Circuit Court decision may have correctly concluded that there was insufficient evidence for them to come to this conclusion. The consent form that was used, for example, was general and vague, providing simply that "attending physicians, members of the House Staff, and the Medical University Clinics have my permission to reveal information to appropriate agencies and individuals where it becomes necessary to protect the welfare of myself/ the patient and/or the community." Far from being evidence that informed consent to share incriminating evidence of drug use with the police was obtained, the form is evidence that it was not. Nothing in the form indicated to the patient that her consent could lead to arrest and imprisonment.

Since the university's policy was discontinued in 1994, and since no other hospital or state in the country has adopted such a policy, the Court's decision has no immediate effect on medical practice. It will, however, discourage others from adopting a similar policy.

\section{THE CONCURRING AND DISSENTING OPINIONS}

Justice Anthony Kennedy wrote a concurring opinion that no other justice joined. Kennedy's point seems to be that cocaine use during pregnancy is terrible and that the state has the authority to oppose and punish it, although he agrees that the Fourth Amendment limits what the state can do. In his words, the 
state has a legitimate interest in fetal life and is legitimately concerned with "the grave risk to the life and health of the fetus, and later the child, caused by cocaine ingestion. . . . South Carolina can impose punishment upon an expectant mother who has so little regard for her own unborn that she risks causing him or her lifelong damage and suffering."

Justice Antonin Scalia wrote a dissenting opinion for himself, Chief Justice William Rehnquist, and Justice Clarence Thomas. His opinion is perhaps most notable for its peculiar view of physicians and the doctor-patient relationship. Scalia believes that as long as the pregnant women consented to having their urine taken, it is irrelevant whether or not they knew what it would be tested for or who would obtain the test results. In this regard, he compared the relationship between a doctor and a patient to that between a suspected criminal and a police informant who has gained the confidence of a suspect. Information voluntarily disclosed by the suspect to the police informant can be used against the suspect. Scalia thinks the same principle should apply to patients. In his words, "information obtained through violation of a relationship of trust is obtained consensually, and is hence not a search.”

Even if this conclusion were to be rejected, Scalia argued, the special-needs exception should still apply: there is no difference, argued Scalia, between the actions of the physicians in this case and their actions in adherence to specific statutes that require them to report certain findings, such as gunshot wounds, to the police. Scalia compared physicians to probation officers, seeing no difference between a probation officer's search of a parolee's home for a gun and the physician's search of a patient's body for cocaine. He concluded with his view that the primary purpose of the policy at the Medical University of South Carolina was not law enforcement but the provision of health benefits to the women through the identification of a "drug-impaired mother and child for necessary medical treatment."

\section{THE FOURTH AMENDMENT AND PHYSICIANS}

For more than a decade, it has seemed that the war on drugs in the United States would gut the Fourth Amendment. ${ }^{9}$ The trend toward approving searches of urine for the presence of drugs, however, has now been stalled, if not stopped. The reasonable expectation of privacy in the doctor-patient relationship renders unreasonable under the Fourth Amendment nonconsensual searches for the presence of illegal drugs as part of a plan to turn this information over to the police. As the majority of the Court stressed, it is one thing to require physicians to report certain findings from the ordinary course of administering treatment, such as evidence of child abuse or neglect or even gunshot wounds. It is another thing for physicians to work directly with the police to search for evidence of criminal behavior. In the first instance, the physician only practices medicine and only performs tests and procedures that are medically indicated for the care of the patient. In the second instance, the physician becomes an agent of the police, conducting a criminal investigation that is outside the domain of medicine and certainly not expected by patients.

There is, nonetheless, some tension inherent in mandatory reporting laws that the Court does not acknowledge. These deserve attention. Reporting statutes that are aimed at preventing harm to children - such as the reporting of child abuse and neglect to state agencies charged with protecting children can be seen as consistent with the physician's obligation to the child. No parent has (or should have) the reasonable expectation that the physician will keep evidence of child abuse or neglect from the state's child-protection services, because both the physician and the state have obligations to act in the best interests of children by protecting them from serious harm. Moreover, the child-protection-services agency is not a police or law-enforcement agency; its only function is to protect the welfare of children by providing protective services to them.

Mandatory reporting of gunshot wounds and knife wounds, however, is more difficult to reconcile with the duties of physicians, which should be to care for the wounded person (who can report the source of the wound to the authorities himself or herself) rather than try to identify the assailant. Such reporting can, however, be seen as protective of the patient insofar as it triggers a police hunt for the assailant, and this goal is consistent with the patient's interests. Moreover, the patient is not being accused of a crime. Nonetheless, as the Court recognizes, the more physicians and nurses become entangled in law enforcement, the more they resemble agents of the police (and police informants and probation officers) rather than health care professionals. Physicians' role in law enforcement, in turn, undermines the trust patients place in them and thus the very ability of physicians to practice medicine; distrustful patients will not be candid with physicians and may even avoid them altogether. ${ }^{10,11}$ During pregnancy, the avoidance of prenatal care can be as devastating to the fetus as drug abuse.

Medical research fails to support the contention that the exposure of a fetus to cocaine is uniquely harmful. ${ }^{12}$ Rather, the evidence supports the hypothesis that cocaine exposure is itself correlated with other harmful factors, including poverty, malnutrition, and exposure to tobacco, marijuana, and alcohol. ${ }^{12,13}$ Thus, there is no medical justification for special intervention related only to fetal exposure to cocaine.

\section{FETUSES AND THE COURT}

The South Carolina case is about the Fourth Amendment and its prohibition of unreasonable 
searches, but it also tells us something about the views of the individual justices with regard to the power of the states to protect the fetus from its mother. The justices line up almost exactly as they did on the 2000 partial-birth-abortion case. Those who believed the state has the authority to prohibit so-called partialbirth abortions also approved of physicians' working closely with the police to screen the urine of impoverished pregnant women for cocaine. As in the partial-birth-abortion case, the dissenters found both medical practice and medical ethics irrelevant to their conclusions. ${ }^{44,15}$

As in the abortion case, Justice Kennedy wrote a separate opinion, although in the drug-testing case he joined the majority instead of the minority. In both cases, however, he saw the state's interest in protecting fetal life and health as stronger than the pregnant woman's interest in her own life and health. In both cases he also approved of state laws designed to force pregnant women to act in ways that the state believed were best for the life or health of the fetus. In the drug-testing case, Kennedy supports state laws that criminalize behavior during pregnancy that he believes harms the fetus and thus the child and that treat pregnant women more severely than others who commit the same crime. He sees punishing the mother after the birth of the child as appropriate, although it is difficult to see how putting a new mother in jail helps her newborn baby or her other children.

In coming to his conclusion, Kennedy ignores the reasoning behind the previous decision of the Court in the 1991 case of Johnson Controls. ${ }^{16}$ In that case, the question was whether a private employer could, consistent with Title VII of the Civil Rights Act of 1964 and the Pregnancy Discrimination Act of 1978, exclude women who could become pregnant from working in jobs that exposed them to lead because such exposure could harm fetuses. The Court found that being infertile is not "a bona fide occupational qualification" for making batteries. Put another way, employers cannot convert a general desire to protect the health of fetuses into a job qualification, because this would effectively exclude almost all women from the job. In the Court's words, "women as capable of doing their job as their male counterparts may not be forced to choose between having a child and having a job." 16 Although Kennedy agreed with the holding in that case, he joined a concurring opinion of Justice Byron White that argued that under other circumstances it might be reasonable for an employer to consider the fetus a "third party" whose safety was, like that of its customers, its responsibility.

In Johnson Controls, the Court noted that Congress had left the welfare of the next generation to parents, not employers, and wrote that "Decisions about the welfare of future children must be left to the parents who conceive, bear, support, and raise them rather than to the employers who hire those parents." 16 The same reasoning applies to drug abuse. Drug abuse is an important problem, as is exposure to lead. But to penalize pregnant women more than other women and men for the same act makes pregnancy itself the relevant variable. Doing so deprives women of their rights for no other reason than that they are pregnant. Johnson Controls was about interpreting a statute, whereas the South Carolina case involves an interpretation of the Constitution. Nonetheless, the rationale of fetal protection claimed by the supporters of the policies in both cases is the same. And in both cases, the Court concluded that the rights of women (whether statutory or constitutional) are not automatically forfeited because of pregnancy.

Fetal protection cannot reasonably be used to justify uniquely restricting or criminalizing the activities of pregnant women. ${ }^{17}$ This would start us down the slippery slope of controlling all behaviors of pregnant women, criminal or not, that might affect the health of their fetus - not only alcohol use and smoking, but also working at certain jobs and engaging in certain sports. ${ }^{18,19}$

Remarkably, Justice Marshall's prediction that the war on drugs would spell the demise of the Fourth Amendment now appears far less likely to come true. A Court that strongly supports both law enforcement and the war on drugs has finally declared unequivocally that there are limits on the tactics that can be used in that war, and some of these limits are set by the Fourth Amendment.

\section{REFERENCES}

1. Skinner v. Railway Labor Executives' Association, 489 U.S. 602 (1989). 2. Siegel B. In the name of the children. Los Angeles Times Magazine. August 7, 1994:14.

3. National Treasury Employees Union v. Von Raab, 489 U.S. 656 (1989). 4. Annas GJ. Crack, symbolism, and the constitution. Hastings Cent Rep 1989;19:1935-7.

5. Ferguson v. City of Charleston, 186 F.3d 469 (4th Cir. 1999)

6. Ferguson v. City of Charleston, 121 S.Ct. 1281 (2001).

7. Veronia School Dist. 47J v. Acton, 515 U.S. 646 (1995).

8. Chandler v. Miller, 520 U.S. 305 (1997).

9. Gantz LH. A nation of suspects: drug testing and the Fourth Amendment. Am J Public Health 1989;79:1427-31.

10. Mariner WK, Glantz LH, Annas GJ. Pregnancy, drugs, and the perils of prosecution. Criminal Justice Ethics 1990;9:30-41.

11. Paltrow LM. When becoming pregnant is a crime. Criminal Justice Ethics 1990;9:41-7.

12. Frank DA, Augustyn M, Knight WG, Pell T, Zuckerman B. Growth, development, and behavior in early childhood following prenatal cocaine exposure: a systematic review. JAMA 2001;285:1613-25.

13. Chavkin W. Cocaine and pregnancy - time to look at the evidence. JAMA 2001;285:1626-8.

14. Stenberg v. Carhart, 520 U.S. 914 (2000)

15. Annas GJ. "Partial-birth abortion" and the Supreme Court. N Engl J Med 2001;344:152-6.

16. International Union v. Johnson Controls, 499 U.S. 187 (1991).

17. Annas GJ. Fetal protection and employment discrimination - the Johnson Controls case. N Engl J Med 1991;325:740-3.

18. Green V. Doped up, knocked up, and . . . locked up? The criminal prosecution of women who use drugs during pregnancy. New York: Garland, 1993.

19. Roberts $D$. The challenge of substance abuse for family preservation policy. In: Journal of health care law \& policy. Vol. 3. Baltimore: University of Maryland School of Law, Law \& Health Care Program, 1999:72-82.

Copyright (C) 2001 Massachusetts Medical Society. 